\title{
Responses of native and invasive woody seedlings to combined competition and drought are species-specific
}

\author{
Andrea Bueno 1, Karin Pritsch ${ }^{2}$ and Judy Simon 1,3 \\ ${ }^{1}$ Plant Interactions Ecophysiology Group, Department of Biology, University of Konstanz, Universitätsstrasse 10, 78457 Konstanz, Germany; ${ }^{2}$ Institute of Biochemical Plant \\ Pathology, Helmholtz Zentrum München, Deutsches Forschungszentrum für Gesundheit und Umwelt GmbH, Ingolstädter Landstrasse 1, 85764 Oberschleißheim, \\ Neuherberg, Germany; ${ }^{3}$ Corresponding author (judy.simon@uni-konstanz.de)
}

\begin{abstract}
Woody species invasions are a major threat to native communities with intensified consequences during increased periods of summer drought as predicted for the future. Competition for growth-limiting nitrogen $(\mathrm{N})$ between native and invasive tree species might represent a key mechanism underlying the invasion process, because soil water availability and $\mathrm{N}$ acquisition of plants are closely linked. To study whether the traits of invasive species provide an advantage over natives in Central Europe in the competition for $\mathrm{N}$ under drought, we conducted a greenhouse experiment. We analyzed the responses of three native (i.e., Fagus sylvatica $L$., Quercus robur $L$. and Pinus sylvestris $L$.) and two invasive woody species (i.e., Prunus serotina Ehrh. and Robinia pseudoacacia L.) to competition in terms of their organic and inorganic $\mathrm{N}$ acquisition, as well as allocation of $\mathrm{N}$ to $\mathrm{N}$ pools in the leaves and fine roots. In our study, competition resulted in reduced growth and changes in internal $\mathrm{N}$ pools in both native and invasive species mediated by the physiological characteristics of the target species, the competitor, as well as soil water supply. Nitrogen acquisition, however, was not affected by competition indicating that changes in growth and $\mathrm{N}$ pools were rather linked to the remobilization of stored $\mathrm{N}$. Drought led to reduced $\mathrm{N}$ acquisition, growth and total soluble protein- $\mathrm{N}$ levels, while total soluble amino acid- $\mathrm{N}$ levels increased, most likely as osmoprotectants as an adaptation to the reduced water supply. Generally, the consequences of drought were enhanced with competition across all species. Comparing the invasive competitors, $P$. serotina was a greater threat to the native species than $R$. pseudoacacia. Furthermore, deciduous and coniferous native species affected the invasives differently, with the species-specific responses being mediated by soil water supply.
\end{abstract}

Keywords: inorganic nitrogen, nitrogen acquisition, nitrogen metabolites, nitrogen pools, nitrogen uptake, organic nitrogen, plant competition, reduced soil water availability, temperate forests, woody invaders.

\section{Introduction}

Invasion of natural habitats by exotic species is considered a major aspect of anthropogenic global change (Vitousek et al. 1997, Ricciardi 2007). In forest ecosystems, successful plant invasions have a negative impact on the structure and composition of plant and microbial communities, as well as forest biogeochemical processes (Castro-Diez et al. 2006, Corbin and D'Antonio 2012). For example, invasives can suppress the recruitment and growth of native plant species, affect carbon pools and nutrient fluxes, and modify litter quality and decomposition (Ehrenfeld et al. 2001, Ehrenfeld 2003, Vilà et al. 2011). As a result, forest functioning is altered and the provision of ecosystem services may be impaired (Holmes et al. 2009, Vilà et al. 2011, Wardle and Peltzer 2017). Invasive plant species commonly display functional traits and growth strategies that improve resource capture and favor reproduction including high seed production (Mason et al. 2008), specific leaf area (SLA; Grotkopp and Rejmánek 2007, Leishman et al. 2007), photosynthetic rates (Pattison et al. 1998, McDowell 2002), relative growth rates (Grotkopp and Rejmánek 2007), root biomass (Broadbent et al. 2018) and/or specific root length (SRL; Dawson 2015). These traits contribute to the successful establishment and dispersal of invasive species in 
new habitats by enhancing their competitive ability. For example, invasive Prunus serotina and Robinia pseudoacacia produce more biomass to the detriment of slower growing of native Quercus robur and Carpinus betulus when grown in competition (Kawaletz et al. 2013).

A key resource in the competition between native and invasive plant species is plant-growth limiting nitrogen $(\mathrm{N})$ (Littschwager et al. 2010, Eller and Oliveira 2017). The competitive ability of plants to acquire $\mathrm{N}$ is determined by plant morphological (e.g., density and length of root hairs) and physiological (e.g., $\mathrm{N}$ uptake capacity, expression and activity of transporters in root cells) traits, as well as species-specific plasticity in these traits (Casper and Jackson 1997), but also the support of symbionts such as mycorrhiza (e.g., Näsholm et al. 2009) and/or $\mathrm{N}_{2}$-fixing bacteria (Bueno et al. 2019). Previous studies investigating the effects of competition for $\mathrm{N}$ found plasticity in the $\mathrm{N}$ uptake capacity of trees with increases or decreases in response to interspecific competition which, however, depended on the competing species, environmental conditions and available $\mathrm{N}$ sources (e.g., inorganic vs organic N) (Simon et al. 2010, 2014, Li et al. 2015, Bueno et al. 2019). For example, Fagus sylvatica increased organic $\mathrm{N}$ acquisition in competition with Acer pseudoplatanus compared with intraspecific competition at high but not low soil $\mathrm{N}$ availability (Li et al. 2015): with ambient but not reduced light, organic $\mathrm{N}$ acquisition decreased in competition with A. pseudoplatanus, reflecting a better adaptation of $F$. sylvatica to low light conditions compared with $A$. pseudoplatanus (Simon et al. 2014). The utilization of different $\mathrm{N}$ sources likely provides an advantage when competing for $\mathrm{N}$ (McKane et al. 2002, Simon et al. 2014) with a high potential to drive niche differentiation and species coexistence (McKane et al. 2002, Ashton et al. 2010, Boudsocq et al. 2012). In the context of competition between native and invasive species, the preference of different $\mathrm{N}$ forms in competition (i.e., one species favouring organic $\mathrm{N}$, whereas the other prefers inorganic $\mathrm{N}$ sources) might provide an important mechanism to effectively avoid competition for $\mathrm{N}$. To our knowledge, this theory has mostly been tested for non-woody species (Fraterrigo et al. 2011, Huangfu et al. 2016) and only recently for tree species (but see Bueno et al. 2019).

The threat of invasive species to European forests might become even more severe in light of the predicted climate changes for Central Europe. In Bueno et al. (2019), the responses of three native and two invasive tree species (i.e., the same species as used here) to high soil $\mathrm{N}$ availability were investigated due to the expected increase in atmospheric $\mathrm{N}$ deposition (Rennenberg et al. 2009). In the present study, responses of native and invasive tree species to competition for $\mathrm{N}$ are investigated under drought conditions. Drought periods in summer are expected to increase in frequency and severity (Spinoni et al. 2017). Thus, understanding the consequences of drought on the outcome of competition for $\mathrm{N}$ between native and invasive woody plant species is crucial. Nitrogen dynamics in both plant and soil are tightly linked to water availability (Gessler et al. 2017): for example, drought negatively affects soil $N$ mineralization processes resulting in reduced plant available $\mathrm{N}$ in the rhizosphere (Simon et al. 2017), soil N diffusion and mass flow (Rennenberg et al. 2006), and the activity of root proteins related to $\mathrm{N}$ acquisition (Bista et al. 2018). Reduced mycorrhizal colonization might additionally lead to less $\mathrm{N}$ transfer to plants (Nilsen et al. 1998). Therefore, also the competition for $\mathrm{N}$ between plants is altered with drought. For example, in studies by Fotelli et al. $(2001,2002)$ the combination of drought and competition with fast-growing Rubus fruticosus resulted in impaired inorganic $\mathrm{N}$ acquisition and water status for $\mathrm{F}$. sylvatica seedlings, as well as increased amino acid levels due to protein degradation in the leaves to act as osmoprotectants. However, whether invasive species have an advantage over native species in the competition for $\mathrm{N}$ under drought scenarios is still unknown, despite woody species invasions becoming a major concern in forests around the globe (Lamarque et al. 2011).

We conducted a greenhouse experiment to study the responses of three native and two invasive woody plant species to different competitors and drought in terms of organic and inorganic $\mathrm{N}$ acquisition as well as allocation of $\mathrm{N}$ to $\mathrm{N}$ pools in the leaves and fine roots. As native species we chose some of the most abundant and widespread species of Central European forests (Ellenberg and Leuschner 2010, Eaton et al. 2016, Houston et al. 2016), which differ in physiological traits and growth strategies: (i) European beech (Fagus sylvatica L, Fagaceae), a drought-sensitive slow growing species (Houston et al. 2016), (ii) pedunculated oak (Quercus robur L., Fagaceae), a drought-tolerant slow growing species (Eaton et al. 2016) and (iii) Scots pine (Pinus sylvestris L., Pinaceae), a drought-tolerant fast growing conifer (Kuster et al. 2013a, Sohn et al. 2016). The two invasive tree species are originally from North America, were first introduced in Europe in the 17th century and are now widely distributed due to their use in reforestation programmes and considered two of the most frequent and important woody invaders in Central European forests (Campagnaro et al. 2018): (i) black cherry (Prunus serotina Ehrh., Rosaceae), a fast growing species producing cyanogenic compounds (Csiszár 2009), and (ii) black locust (Robinia pseudoacacia L., Leguminosae), a fast growing, $\mathrm{N}_{2}$-fixing species (Robakowski et al. 2016, Vitková et al. 2017). Both, the remobilization of $N$ from cyanogenic compounds and the ability to symbiotically fix $\mathrm{N}_{2}$ allow these two invasive species to acquire additional $\mathrm{N}$ independently from soil $\mathrm{N}$ supply, which could thus serve as alternate sources of $N$. From here on, species used in this study will be referred to using their genus, i.e., Fagus, Quercus, Pinus, Prunus and Robinia.

Our general research aim was to evaluate whether $\mathrm{N}$ acquisition and allocation of $\mathrm{N}$ to $\mathrm{N}$ pools of native and invasive species 
shift in response to drought and different competitors reflecting their functional traits, i.e., growth rate (slow-growing vs fast-growing), drought tolerance (drought-tolerant vs droughtsensitive) and/or the ability to access alternative sources of $\mathrm{N}$ (e.g., via remobilization of $\mathrm{N}$ stored in cyanogenic compounds or symbiotic $\mathrm{N}_{2}$ fixation). Our specific hypotheses were: (i) Drought generally reduces inorganic and organic $\mathrm{N}$ acquisition because $\mathrm{N}$ uptake from the soil strongly depends on water availability (Gessler et al. 2004, Rennenberg et al. 2006). (ii) Species-specific coping mechanisms (related to their functional traits) lead to changes in the allocation of $\mathrm{N}$ to $\mathrm{N}$ pools in the leaves and fine roots, because generally with drought less $N$ is acquired from the soil (Gessler et al. 2017). (iii) Nitrogen acquisition and allocation of $\mathrm{N}$ to $\mathrm{N}$ pools of a given species change depending on the species' functional traits and the competitor. For example, competition between a slow and a fast grower leads to a decrease in $\mathrm{N}$ acquisition and allocation to $\mathrm{N}$ pools in the slow growing species because of the fast grower's higher $\mathrm{N}$ demand (Reich 2014). (iv) Native and invasive species differ in their preference for organic and inorganic $\mathrm{N}$ sources, resulting in avoidance of competition for $\mathrm{N}$ (Fraterrigo et al. 2011, Huangfu et al. 2016).

\section{Materials and methods}

\section{Plant material and growth conditions}

One-year-old seedlings of all species were purchased from Müller Münchehof Pflanzen GmbH (Seesen/Münchehof, Germany) and planted in different combinations (i.e., two seedlings per pot, see Experimental design section) in a 1:1 mixture of sand and vermiculite in 3 I plastic pots $(25 \mathrm{~cm} \times 12 \mathrm{~cm})$ at the end of November 2015. Pots stayed outdoors over winter and spring and were watered regularly. They were brought into the greenhouse at the University of Konstanz on 20 June 2016 after leaf development. For the following 7 days, all pots were watered regularly with sufficient tap water, and received on two occasions $100 \mathrm{ml}$ of an artificial low $\mathrm{N}$ nutrient solution containing $100 \mu \mathrm{M} \mathrm{KNO}_{3}, 90 \mu \mathrm{M} \mathrm{CaCl}_{2} * 2 \mathrm{H}_{2} \mathrm{O}, 70 \mu \mathrm{M}$ $\mathrm{MgCl}_{2} * 6 \mathrm{H}_{2} \mathrm{O}, 50 \mu \mathrm{M} \mathrm{KCl}, 24 \mu \mathrm{M} \mathrm{MnCl}_{2} * 4 \mathrm{H}_{2} \mathrm{O}, 20 \mu \mathrm{M} \mathrm{NaCl}$, $10 \mu \mathrm{M} \mathrm{AlCl}_{3}, 7 \mu \mathrm{M} \mathrm{FeSO}_{4} * 7 \mathrm{H}_{2} \mathrm{O}, 6 \mu \mathrm{M} \mathrm{K}_{2} \mathrm{HPO}_{4}, 1 \mu \mathrm{M} \mathrm{NH}_{4} \mathrm{Cl}$, $25 \mu \mathrm{M}$ glutamine and $25 \mu \mathrm{M}$ arginine, mimicking the soil solution of a low $\mathrm{N}$ field site (Dannenmann et al. 2009). The pots were subjected to natural light conditions and day length regime $(16 / 8 \mathrm{~h}$, day/night). Air temperature was $23.5 \pm 2.3$ ${ }^{\circ} \mathrm{C} / 21.0 \pm 2.4^{\circ} \mathrm{C}$ (day/night, mean \pm standard deviation), and relative humidity was $63.1 \pm 9.3 \% / 71.3 \pm 8.8 \%$ (day/night, mean \pm standard deviation) for the duration of the experiment. With increasing duration of the drought treatment, some individuals started to show signs of wilting. To ensure sufficient replication for each species and treatment, we did the ${ }^{15} \mathrm{~N}$ uptake experiments followed by the harvest after four weeks.

\section{Experimental design}

The experiment was conducted in a fully orthogonal design with two factors, 'water availability' (i.e., control or drought) and 'competitor' (interspecific competition with two or three different competitors). Seedlings were planted in native-invasive interspecific competition (i.e., one seedling of a native species and one seedling of an invasive species per pot). Pots were established for every combination of native species and invasive species. For each species, a total of 24 pots was setup for each combination of native-invasive, summing up to a total of 144 pots. Pots were assigned to either the control or the drought treatment (i.e., $n=12$ per combination of species, competitor and soil water availability). For the drought treatment, irrigation was fully stopped starting 27 June until the final harvest from 21 to 27 July, while for the control treatment irrigation continued with sufficient tap water supply every second day. To confirm that water availability was significantly reduced in the respective treatment, we measured soil water content every second day for three pots per combination of species, soil water availability treatment and competitor, by inserting a probe into the soil in three different locations in each pot ( $\mathrm{HH}_{2}$ Moisture Meter, Delta-T Devices, Cambridge, UK). Soil water content in the drought treatment was $7.2 \pm 2.4 \%$ (mean \pm standard deviation) and significantly lower than in the control $24.0 \pm 2.5 \%$ (mean \pm standard deviation) at the end of the experiment. $\delta^{13} \mathrm{C}$ values in the leaves (see Table S6 available as Supplementary Data at Tree Physiology Online) were higher in the drought treatment compared with the control at the time of harvest, indicating drought stress for Fagus, Quercus and Robinia depending on the competitor, while for Pinus and Prunus no differences were found.

\section{${ }^{15} \mathrm{~N}$ uptake experiments}

To quantify inorganic (i.e., ammonium and nitrate) and organic (i.e., glutamine and arginine) net $\mathrm{N}$ uptake capacity of the seedlings' fine roots, the ${ }^{15} \mathrm{~N}$ enrichment technique was used as described by Gessler et al. (1998) and modified by Simon et al. (2010). Seedlings were carefully removed from the pots and the roots washed thoroughly with tap water to remove any remaining substrate. Then, fine roots still attached to the seedlings were incubated in the same artificial low $\mathrm{N}$ solution as used during plant growth (see above) containing all four $\mathrm{N}$ sources but only one labelled as either ${ }^{15} \mathrm{NH}_{4}{ }^{+},{ }^{15} \mathrm{NO}_{3}{ }^{-}$, ${ }^{13} \mathrm{C} /{ }^{15} \mathrm{~N}$-glutamine or ${ }^{13} \mathrm{C} /{ }^{15} \mathrm{~N}$-arginine. Controls with no label were included to account for natural abundance in the fine roots ( $n=4-6$ per $\mathrm{N}$ source including controls with no label, per species, competitor and soil water availability treatment). The roots not used for incubation were wrapped in wet tissue to prevent desiccation for the duration of the ${ }^{15} \mathrm{~N}$ uptake experiment. After $2 \mathrm{~h}$ of incubation, the fine roots were cut from the seedling and washed twice in $0.5 \mathrm{M} \mathrm{CaCl}_{2}$ solution to remove the incubation solution from the root surface. The 
fresh weight of the fine roots was determined, and after ovendrying for $48 \mathrm{~h}$ at $60^{\circ} \mathrm{C}$, their dry weight was determined. Amino acids were ${ }^{13} \mathrm{C} /{ }^{15} \mathrm{~N}$-labelled to determine whether they were taken up as intact molecules (Simon et al. 2011). Net uptake capacity of glutamine and arginine was lower based on ${ }^{13} \mathrm{C}$ compared with that on ${ }^{15} \mathrm{~N}$ incorporation, indicating that amino acids degraded in the solution or on the surface of the roots, and/or the respiration of amino acid-derived carbon (C) inside the roots (Simon et al. 2011). Incubation took place between 10 a.m. and 2 p.m. to avoid diurnal variation in net $\mathrm{N}$ uptake capacity (Gessler et al. 2002).

\section{Harvest and quantification of growth and biomass indices}

After the ${ }^{15} \mathrm{~N}$ uptake experiment, seedlings were separated into leaves, stems and roots. Their fresh weight was determined, then all tissues were oven-dried for $48 \mathrm{~h}$ at $60^{\circ} \mathrm{C}$ and their dry weight was determined. Before oven-drying, a subsample of 8-10 representative leaves was collected from each seedling and their leaf area measured (LI-3100C Area Meter, LI-COR, Lincoln, NE, USA) to calculate SLA. Likewise, a subsample of fine roots was collected from each seedling. stained, scanned and total length measured (WinRhizo 2012, Regent Instruments Inc., Quebec, Canada) to calculate SRL based on Liu and van Kleunen (2017). Furthermore, samples of leaves and fine roots were collected from each seedling to quantify total soluble amino acid-N and total soluble protein$\mathrm{N}$ contents. These samples were shock-frozen in liquid $\mathrm{N}_{2}$ immediately after sampling and determining their fresh weight, and then stored at $-80^{\circ} \mathrm{C}$ until further analyses. Root:shoot ratio was calculated as the relation between total belowground biomass (i.e., root biomass) and total aboveground biomass (i.e., leaves and stem biomass). For each seedling, RGR was calculated according to the equation: RGR $=\left(\ln b_{2}-\ln b_{1}\right)$ $* \mathrm{t}^{-1}$, where $b_{1}$ is total seedling biomass ( $\mathrm{g}$ dry weight ( $\mathrm{g}$ $\mathrm{dw})$ ) at the initial harvest, $b_{2}$ is total seedling biomass ( $\mathrm{g} \mathrm{dw}$ ) at the final harvest and $t$ is the time period in days between the initial and the final harvest (Grubb et al. 1996). Initial seedling biomass was determined on three to four pots per species, competitor and soil water availability treatment that were harvested immediately before commencing the drought treatment.

Quantification of total $\mathrm{N}$ and $\mathrm{C},{ }^{15} \mathrm{~N}$, and ${ }^{13} \mathrm{C}$ in fine roots and $\delta^{13} \mathrm{C}$ in leaves

Dried fine root samples from the ${ }^{15} \mathrm{~N}$ uptake experiment were ground using a ball mill (TissueLyser, Retsch, Haan, Germany) to a fine homogeneous powder. Aliquots of $1.2-2.4 \mathrm{mg}$ were weighed into $4 \times 6 \mathrm{~mm}$ tin capsules (IVA Analysentechnik, Meerbusch, Germany) for analyses with an isotope ratio mass spectrometer (Delta V Advantage, Thermo Electron, Dreieich, Germany) coupled to an elemental analyzer (Euro EA, Eurovector, Milano, Italy). $\delta$ values were calculated using a laboratory standard (acetanilide) that was part of every sequence in intervals also used in different weights to determine isotope linearity of the system. The laboratory standard was calibrated against several suitable international isotope standards (IAEA, Vienna, Austria). Final correction of isotope values was done with several international isotope standards and other suitable laboratory standards which cover the range of ${ }^{15} \mathrm{~N}$ and ${ }^{13} \mathrm{C}$ results. Inorganic and organic $\mathrm{N}$ net uptake capacity $\left(\mathrm{nmol} \mathrm{N} \mathrm{g}^{-1}\right.$ $f w h^{-1} ; f w=$ fresh weight) was calculated based on the incorporation of ${ }^{15} \mathrm{~N}$ into the fine roots according to Kreuzwieser et al. (2002): net $\mathrm{N}$ uptake capacity $=\left(\left({ }^{15} \mathrm{~N}_{l}-{ }^{15} \mathrm{~N}_{n}\right) * \mathrm{~N}_{\text {tot }} *\right.$ $\left.\mathrm{dw} * 10^{5}\right) /(\mathrm{MW} * \mathrm{fw} * \mathrm{t})^{-1}$, where ${ }^{15} \mathrm{~N}_{/}$and ${ }^{15} \mathrm{~N}_{n}$ are the atom\% of ${ }^{15} \mathrm{~N}$ in labelled $\left(\mathrm{N}_{/}\right)$and unlabeled control plants $\left(\mathrm{N}_{n}\right.$, natural abundance), respectively, $N_{\text {tot }}$ is the total $N$ percentage, $M W$ is the molecular weight $\left({ }^{15} \mathrm{~N} \mathrm{~g} \mathrm{~mol}^{-1}\right)$ and $t$ is the incubation time.

\section{Quantification of total soluble protein and total soluble} amino acid levels in leaves and fine roots

To extract total soluble proteins from the leaves and fine roots (Dannenmann et al. 2009), 50 mg aliquots of finely ground frozen samples were incubated in $1.5 \mathrm{ml}$ extraction buffer (50 mM Tris- $\mathrm{HCl}$ pH 8.0, 1 mM EDTA, 15\% (v/v) glycerol, $0.6 \mathrm{mM}$ dithiothreitol, $1 \%$ Triton X-100, 2 EDTA-free protease inhibitor cocktail tablets per $100 \mathrm{ml}$ buffer) at $4{ }^{\circ} \mathrm{C}$ for $30 \mathrm{~min}$ followed by centrifugation for $10 \mathrm{~min}$ at 14,000 r.p.m. and $4{ }^{\circ} \mathrm{C}$. The extraction was done twice to increase the yield. Subsequently, $500 \mu$ of the combined supernatant from both extractions were incubated with $1 \mathrm{ml} 10 \%(\mathrm{v} / \mathrm{v})$ trichloroacetic acid for $10 \mathrm{~min}$ at room temperature and then centrifuged for $10 \mathrm{~min}$ at 14,000 r.p.m. and $4{ }^{\circ} \mathrm{C}$. The resulting protein pellet was dissolved in $1 \mathrm{ml} 1 \mathrm{M} \mathrm{KOH}$. Next, total soluble proteins were quantified following Simon et al. (2010) by adding $1 \mathrm{ml}$ of Bradford reagent to $50 \mu \mathrm{l}$ of extract. Following a $10 \mathrm{~min}$ incubation at room temperature in the dark, the absorbance was measured at $595 \mathrm{~nm}$ in a spectrophotometer (Ultrospec 3100pro, Amersham Biosciences Europe GmbH, Freiburg i.Br., Germany). Bovine serum albumin (BSA) was used as standard.

Total soluble amino acid-N content in the leaves and fine roots were extracted according to Winter et al. (1992): $200 \mu \mathrm{l}$ Hepes buffer ( $5 \mathrm{mM}$ EGTA, $20 \mathrm{mM}$ HEPES, $10 \mathrm{mM} \mathrm{NaF}$ ) and $1 \mathrm{ml} 3.5: 1.5$ (v:v) methanol/chloroform were added to $\sim 50 \mathrm{mg}$ aliquots of finely ground frozen sample and incubated for $30 \mathrm{~min}$ on ice, followed by the addition of $600 \mu \mathrm{l}$ of distilled water and centrifugation for $5 \mathrm{~min}$ at 14,000 r.p.m. and $4{ }^{\circ} \mathrm{C}$. The addition of distilled water and centrifugation was performed twice to increase the yield. Total soluble amino acid- $\mathrm{N}$ content in the leaves and fine roots were quantified according to Liu et al. (2005): $50 \mu \mathrm{l}$ ninhydrin solution was added to a $50 \mu \mathrm{l}$ aliquot of the combined extract and boiled for $30 \mathrm{~min}$. The ninhydrin solution was composed of an equal parts mixture of solution A (i.e., $3.84 \mathrm{~g}$ citric acid, $0.134 \mathrm{~g}$ $\mathrm{SnCl}_{2}$ and $40 \mathrm{ml} 1 \mathrm{M} \mathrm{NaOH}$, filled to $100 \mathrm{ml}$ with distilled 
water at $\mathrm{pH}$ 5) and solution B (i.e., $4 \mathrm{~g}$ ninhydrin in $100 \mathrm{ml}$ ethylene-glycol-monomethyl-ether). Subsequently, the extracts were cooled to room temperature and $1 \mathrm{ml} 50 \%$ isopropanol was added, followed by a $15 \mathrm{~min}$ incubation. The absorption was measured at $570 \mathrm{~nm}$ in a spectrophotometer (Ultrospec 3100pro, Amersham Biosciences Europe GmbH, Freiburg i.Br., Germany). L-glutamine was used as standard.

\section{Statistical analyses}

Two-way permutational ANOVAs (PERMANOVA) based on a Euclidean resemblance matrix between samples (Anderson et al. 2008) were performed for each species to test for differences between water availability and competitor levels using as variables inorganic and organic net $\mathrm{N}$ uptake capacity, total soluble amino acid- $\mathrm{N}$, and total soluble protein- $\mathrm{N}$ contents in the leaves and fine roots, as well as total biomass, root:shoot ratio, SLA, SRL and RGR. PERMANOVAs were performed using 'water availability' (i.e., drought and control) and 'competitor' as fixed orthogonal factors. 'Competitor' consisted of two levels for the native species (i.e., competition with Prunus or Robinia) or three levels for the invasive species (i.e., competition with Fagus, Quercus or Pinus). For significant interactions between factors, post hoc PERMANOVA pair-wise comparisons were performed. To test for differences in $\delta^{13} \mathrm{C}$ in leaves between drought and control for each species grown with different competitors, Mann-Whitney U-tests were performed. Finally, to test for species preferences in net $\mathrm{N}$ uptake capacity of the different $\mathrm{N}$ forms, one-way PERMANOVAs were performed for each combination of species and competitor using ' $N$ source' as factor at both levels of soil water availability. All PERMANOVA analyses were performed using PRIMER 6.0 with the PERMANOVA+ add-on (PRIMER-E Ltd, Plymouth, UK), while Mann-Whitney U-tests were performed using SigmaPlot 14.0 (Systat Software, San Jose, CA, USA).

\section{Results}

Drought effects on $\mathrm{N}$ acquisition and allocation to $\mathrm{N}$ pools in the leaves and fine roots of native and invasive tree seedlings

For all species (both native and invasive), net $\mathrm{N}$ uptake capacity was lower with drought compared with sufficient water supply, but with differences among species regarding which specific $\mathrm{N}$ form was significantly affected and with which competitor (native species: Figure 1, invasive species: Figure 2). Ammonium acquisition, already very low, was reduced further with drought for Prunus and Robinia (Figure 2) regardless of competitor, whereas nitrate acquisition was lower with drought for Fagus, Quercus, Pinus (Figure 1) and Prunus regardless of competitor, and for Robinia only in competition with Quercus and Pinus (Figure 2). Glutamine acquisition was reduced by drought for Pinus (Figure 1), Prunus and Robinia
(Figure 2) regardless of competitor, and for Quercus (Figure 1) only in competition with Robinia, while arginine acquisition was lower with drought for Fagus, Quercus (both Figure 1) and Robinia (Figure 2) regardless of competitor (Table 1 and see Table S1 available as Supplementary Data at Tree Physiology Online).

Drought also led to changes in $\mathrm{N}$ allocation to $\mathrm{N}$ pools in leaves and fine roots. With drought compared with the controls, total soluble protein- $\mathrm{N}$ content was reduced regardless of competitor in the leaves of Fagus and Quercus, and in the fine roots of Prunus, as well as in the fine roots of Robinia in competition with Pinus, while it increased in the fine roots of Robinia in competition with Fagus with drought (Table 1 and see Tables S2-S4 available as Supplementary Data at Tree Physiology Online). Total soluble amino acid- $\mathrm{N}$ content was increased with drought in the fine roots of Pinus and the leaves of Robinia regardless of competitor, as well as in the leaves and fine roots of Quercus in competition with Prunus (Table 1 and see Tables S2-S4 available as Supplementary Data at Tree Physiology Online). However, total soluble amino acid-N levels were lower with drought in the fine roots of Prunus grown in competition with Quercus or Pinus (Table 1 and see Tables S2-S4 available as Supplementary Data at Tree Physiology Online).

Finally, drought resulted in higher $\delta^{13} \mathrm{C}$ values in the leaves of Fagus and Quercus grown in competition with Prunus, and in the leaves of Robinia grown in competition with Quercus or Pinus (see Tables S5 and S6 available as Supplementary Data at Tree Physiology Online). Drought affected also the total biomass, rootshoot ratio, RGR, SLA and SRL of native and invasive species depending on both the target species and the competitor (Table 1 and see Tables S7-S9, Figure S1 available as Supplementary Data at Tree Physiology Online).

Competitor effects on $\mathrm{N}$ acquisition and allocation to $\mathrm{N}$ pools in the leaves and fine roots of native and invasive tree species

For native species, $\mathrm{N}$ acquisition did not change with different invasive competitors, but there were different responses regarding allocation to $\mathrm{N}$ pools (Figure 1). In competition with Prunus compared with Robinia and regardless of soil water availability, Quercus had lower total soluble protein$\mathrm{N}$ content but higher total soluble amino acid- $\mathrm{N}$ content in the fine roots, whereas Pinus had lower total soluble amino acid- $\mathrm{N}$ content and higher total soluble protein- $\mathrm{N}$ content in the leaves, and higher total soluble amino acid$\mathrm{N}$ content in the fine roots (Table 2 and see Tables S2-S4 available as Supplementary Data at Tree Physiology Online). For Fagus, $\mathrm{N}$ allocation to $\mathrm{N}$ pools did not vary with competitor (Table 2 and see Tables S2-S4 available as Supplementary Data at Tree Physiology Online). All native species 
Fagus sylvatica

Quercus robur

Pinus sylvestris
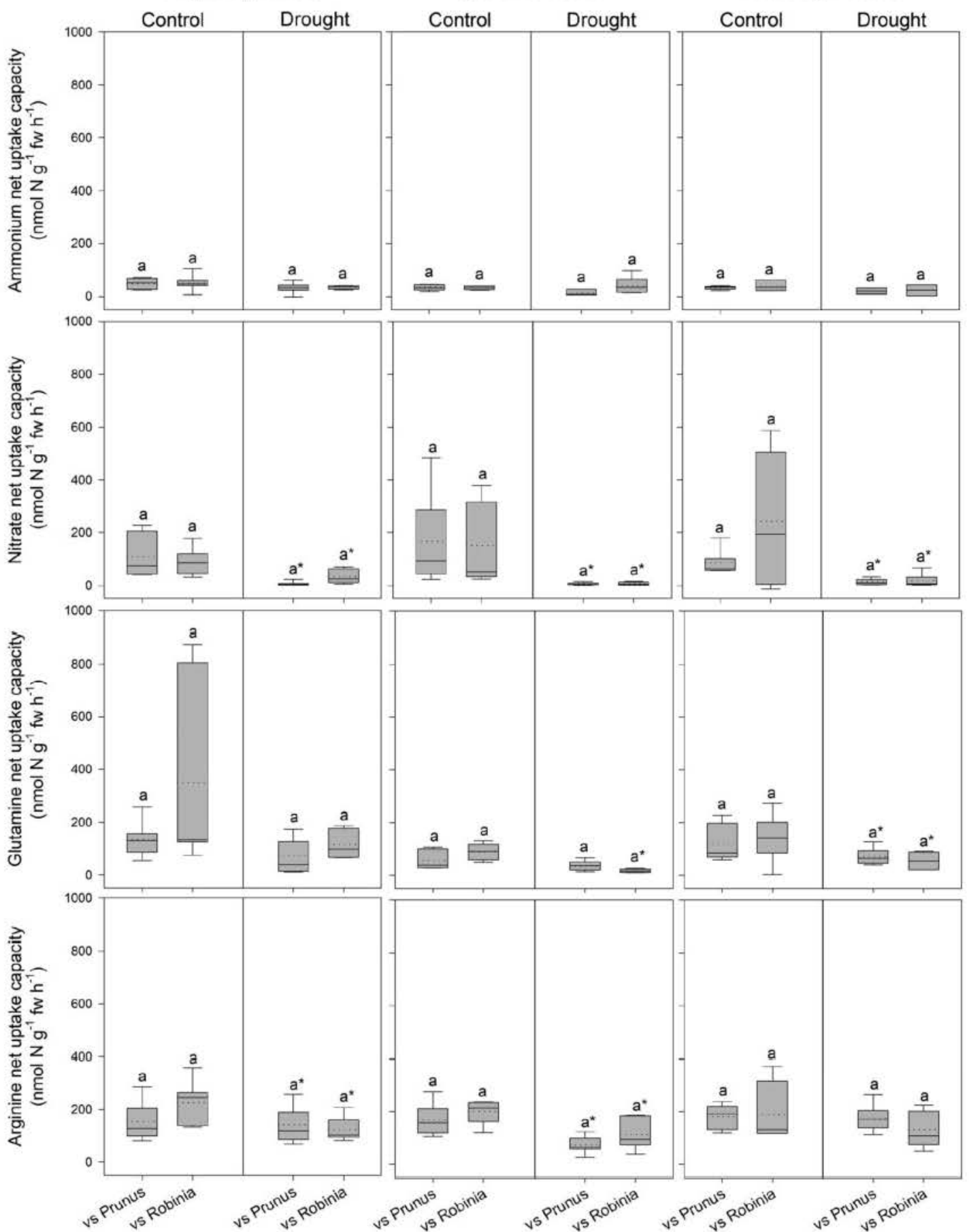

Figure 1. Ammonium, nitrate, glutamine- $\mathrm{N}$ and arginine- $\mathrm{N}$ net uptake capacity (nmol $\mathrm{N} \mathrm{g}^{-1}$ fw h $\mathrm{h}^{-1}$ ) by fine roots of $F$. sylvatica, $Q$. robur and $P$. sylvestris seedlings at control and drought conditions under different competition regimes. vs Prunus $=$ competition with Prunus serotina; vs Robinia $=$ competition with R. pseudoacacia. Box plots show mean (dotted line) and median (continuous line). Different letters indicate significant differences between competition regimes within a specific soil water availability treatment, and asterisks indicate significant differences between control and drought detected using permutational analysis of variance $(P<0.05)$. 
Prunus serotina

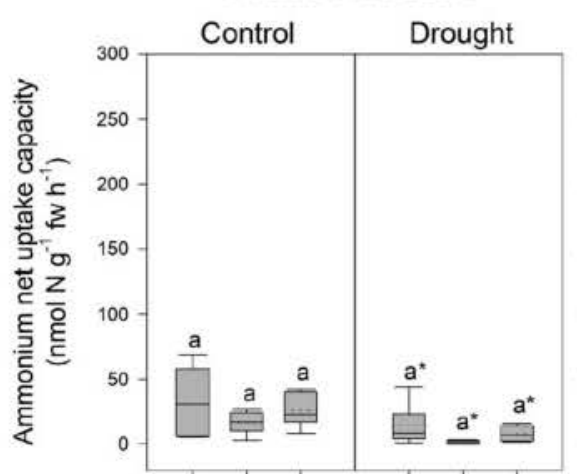

Robinia pseudoacacia
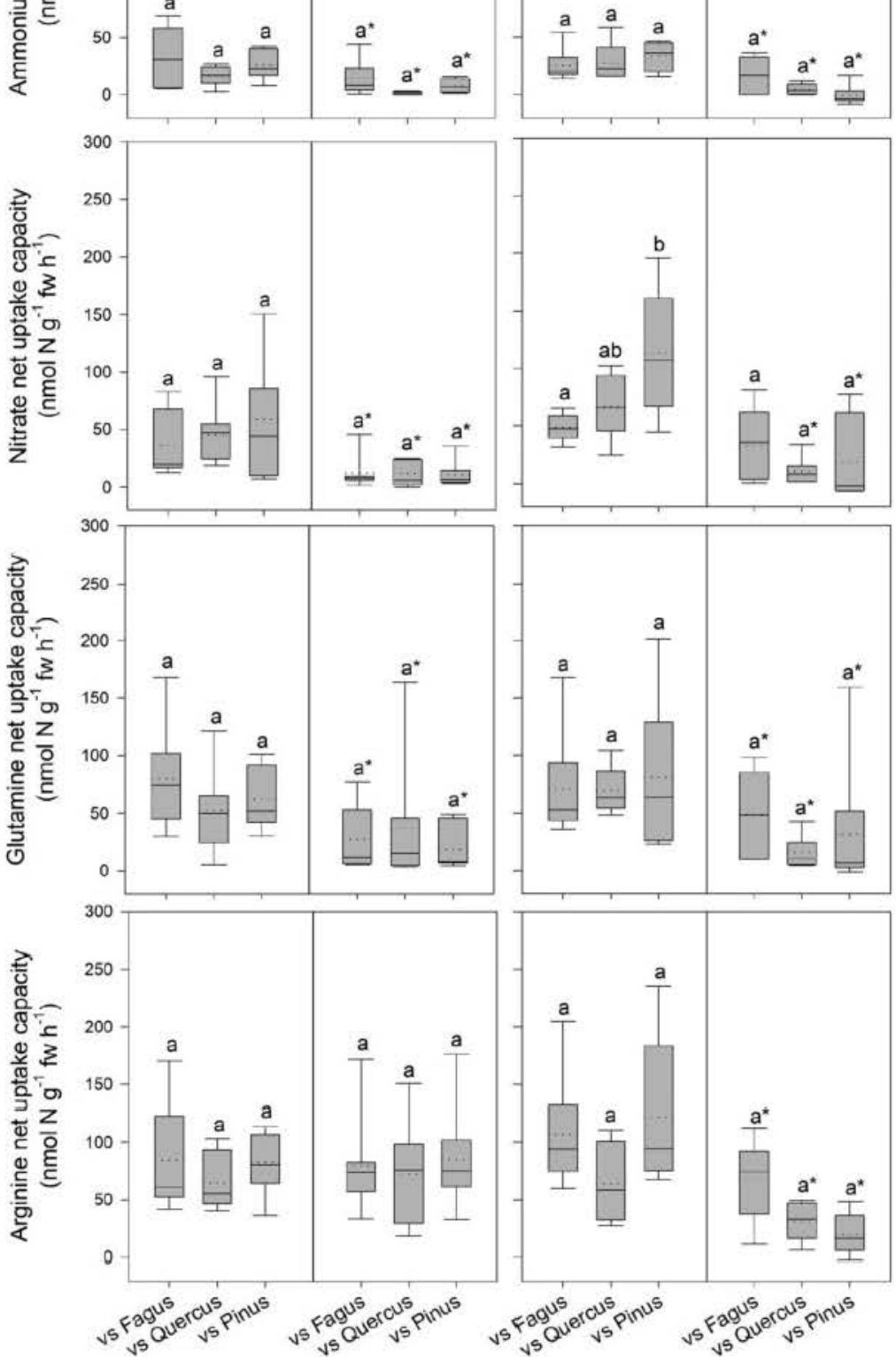

Figure 2. Ammonium, nitrate, glutamine- $\mathrm{N}$ and arginine- $\mathrm{N}$ net uptake capacity $\left(\mathrm{nmol} \mathrm{N} \mathrm{g} \mathrm{fw} \mathrm{h}^{-1}\right.$ ) by fine reots of $P$. serotina and $R$. $p$ seudoacacia seedlings at control and drought conditions under different competition regimes. vs Fagus $=$ competition with F. sylvatica; vs $Q$ uercus $=$ competition with $Q$. robur; vs Pinus = competition with P. sylvestris. Box plots show mean (dotted line) and median (continuous line). Different letters indicate significant differences between competition regimes within a specific soil water availability treatment, and asterisks indicate significant differences between control and drought detected using permutational analysis of variance $(P<0.05)$. 


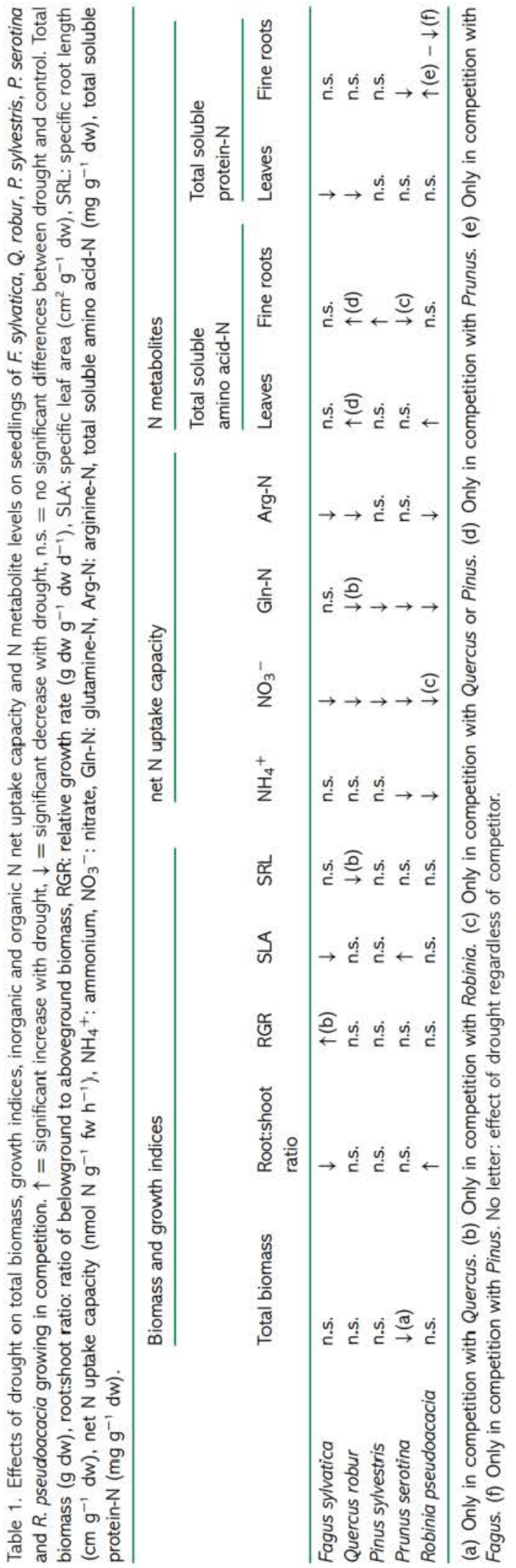

responded differently to the invasive competitors regarding their biomass and growth indices (Table 2 and see Tables S7S9 available as Supplementary Data at Tree Physiology Online).

Similarly, responses of the invasive species depended on competitor and were partly also mediated by soil water availability. Under drought, Prunus seedlings had lower total soluble amino acid-N contents in the fine roots when competing with Quercus compared with Pinus (Table 2 and see Tables S2-S4 available as Supplementary Data at Tree Physiology Online). With sufficient soil water supply, total soluble amino acid-N content was lower in the fine roots of Prunus competing with Fagus than with Quercus or Pinus (Table 2 and see Tables S2S4 available as Supplementary Data at Tree Physiology Online). Prunus seedlings had a lower total soluble amino acid-N content in the leaves when competing with Fagus than with Quercus, and a lower total soluble protein- $\mathrm{N}$ content in the leaves when competing with Fagus or Quercus than with Pinus (Table 2 and see Tables S2, S4 and S10 available as Supplementary Data at Tree Physiology Online). Robinia seedlings responded to competitor with changes in other parameters than Prunus. With drought, Robinia seedlings had higher total soluble protein$\mathrm{N}$ content in the fine roots when competing with Fagus than with Quercus, and higher total soluble protein- $\mathrm{N}$ content in the fine roots competing with Quercus than with Pinus (Table 2 and see Tables S2-S4 available as Supplementary Data at Tree Physiology Online). Under control conditions, Robinia competing with Fagus had a lower nitrate net uptake capacity than when competing with Pinus (Figure 2 and Table 2). Both Prunus and Robinia responded differently with regard to their biomass and growth indices (Table 2 and see Tables S7-S9 and S11 available as Supplementary Data at Tree Physiology Online).

\section{Nitrogen acquisition preferences for different $N$ sources of native and invasive species}

Preferences for certain $\mathrm{N}$ sources were found among species depending on the competitor and soil water availability. Generally, organic $\mathrm{N}$, especially arginine- $\mathrm{N}$, was favored over inorganic $\mathrm{N}$ sources. Quercus and Prunus did not change $\mathrm{N}$ preferences with different competitors or drought (Tables 3 and 4). Fagus preferred organic $\mathrm{N}$ over inorganic $\mathrm{N}$ with drought (Table 3 ). Pinus did not prefer specific $\mathrm{N}$ sources in competition with Robinia with sufficient water supply, but preferred organic $\mathrm{N}$ over inorganic $\mathrm{N}$ with drought and in competition with Prunus regardless of water availability (Table 3 ). Robinia showed a distinct pattern depending on the competitor: with drought, seedlings preferred arginine- $\mathrm{N}$ over inorganic $\mathrm{N}$ in competition with Quercus, but not in competition with Fagus or Pinus (Table 4). With sufficient water supply, Robinia preferred organic over inorganic $\mathrm{N}$ when grown in competition with Fagus, but not with Quercus or Pinus (Table 4). 
Table 2. Effects of competitor on total biomass, growth indices, inorganic and organic $\mathrm{N}$ net uptake capacity, and $\mathrm{N}$ metabolite levels of $F$. sylvatica, Q. robur, $P$. sylvestris, $P$. serotina and $R$. pseudoacacia seedlings. Species A < species B: seedlings competing with species A had significantly lower values than seedlings competing with species B, n.s.: no significant differences between competitors. Total biomass ( $\mathrm{g} \mathrm{dw}$ ), root:shoot ratio: ratio of belowground to aboveground biomass, RGR: relative growth rate $\left(\mathrm{g} \mathrm{dw} \mathrm{g}^{-1} \mathrm{dw} \mathrm{d}^{-1}\right)$, SLA: specific leaf area ( $\mathrm{cm}^{2} \mathrm{~g}^{-1} \mathrm{dw}$ )

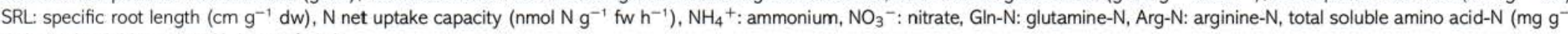
$\mathrm{dw})$, total soluble protein-N ( $\left.\mathrm{mg} \mathrm{g}^{-1} \mathrm{dw}\right)$.

\begin{tabular}{|c|c|c|c|c|c|c|c|c|c|c|c|c|c|}
\hline & \multicolumn{5}{|c|}{ Biomass and growth indices } & \multicolumn{4}{|c|}{ net $\mathrm{N}$ uptake capacity } & \multicolumn{4}{|c|}{$\mathrm{N}$ metabolites } \\
\hline & \multirow[b]{2}{*}{ Total biomass } & \multirow[b]{2}{*}{$\begin{array}{l}\text { Root:shoot } \\
\text { ratio }\end{array}$} & \multirow[b]{2}{*}{ RGR } & \multirow[b]{2}{*}{ SLA } & \multirow[b]{2}{*}{ SRL } & \multirow[b]{2}{*}{$\mathrm{NH}_{4}{ }^{+}$} & \multirow[b]{2}{*}{$\mathrm{NO}_{3}^{-}$} & \multirow[b]{2}{*}{ Gln-N } & \multirow[b]{2}{*}{ Arg- $\mathrm{N}$} & \multicolumn{2}{|c|}{$\begin{array}{l}\text { Total soluble } \\
\text { amino acid-N }\end{array}$} & \multicolumn{2}{|c|}{ Total soluble protein- $\mathrm{N}$} \\
\hline & & & & & & & & & & Leaves & Fine roots & Leaves & Fine roots \\
\hline Fagus sylvatica & n.s. & n.s. & $\begin{array}{l}\text { Robinia < } \\
\text { Prunus (a) }\end{array}$ & n.s. & n.s. & n.s. & n.s. & n.s. & n.s. & n.s. & n.s. & n.s. & n.s. \\
\hline Quercus robur & n.s. & $\begin{array}{l}\text { Prunus < } \\
\text { Robinia }\end{array}$ & $\begin{array}{l}\text { Prunus < } \\
\text { Robinia }\end{array}$ & n.s. & $\begin{array}{l}\text { Robinia }< \\
\text { Prunus } \\
\text { (b) }\end{array}$ & n.s. & n.s. & n.s. & n.s. & n.s. & $\begin{array}{l}\text { Robinia }< \\
\text { Prunus }\end{array}$ & n.s. & $\begin{array}{l}\text { Prunus < } \\
\text { Robinia (a) }\end{array}$ \\
\hline Pinus sylvestris & $\begin{array}{l}\text { Prunus < } \\
\text { Robinia }\end{array}$ & n.s. & n.s. & - & n.s. & n.s. & n.s. & n.s. & n.s. & $\begin{array}{l}\text { Prunus < } \\
\text { Robinia }\end{array}$ & $\begin{array}{l}\text { Robinia < } \\
\text { Prunus }\end{array}$ & $\begin{array}{l}\text { Robinia }< \\
\text { Prunus }\end{array}$ & n.s. \\
\hline Prunus serotina & $\begin{array}{l}\text { Fagus, } \\
\text { Pinus < } \\
\text { Quercus (a) }\end{array}$ & n.s. & $\begin{array}{l}\text { Quercus, } \\
\text { Pinus < } \\
\text { Fagus }\end{array}$ & $\begin{array}{l}\text { Quercus < } \\
\text { Fagus < } \\
\text { Pinus }\end{array}$ & $\begin{array}{l}\text { Quercus < } \\
\text { Fagus } \\
\text { (a) }\end{array}$ & n.s. & n.s. & n.s. & n.s. & $\begin{array}{l}\text { Fagus < } \\
\text { Quercus }\end{array}$ & $\begin{array}{l}\text { Fagus < } \\
\text { Quercus, Pinus } \\
\text { (a) } \\
\text { Quercus }<\text { Pinus } \\
\text { (b) }\end{array}$ & $\begin{array}{l}\text { Fagus, } \\
\text { Quercus < } \\
\text { Pinus } \\
\text { (b) }\end{array}$ & n.s. \\
\hline $\begin{array}{l}\text { Robinia } \\
\text { pseudoacacia }\end{array}$ & n.s. & n.s. & $\begin{array}{l}\text { Fagus, } \\
\text { Quercus } \\
<\text { Pinus }\end{array}$ & n.s. & n.s. & n.s. & $\begin{array}{l}\text { Fagus } \\
<\text { Pinus } \\
\text { (a) }\end{array}$ & n.s. & n.s. & n.s. & n.s. & n.s. & $\begin{array}{l}\text { Pinus < } \\
\text { Quercus < } \\
\text { Fagus (b) }\end{array}$ \\
\hline
\end{tabular}

(a) Only under control conditions. (b) Only with drought. No letter: effect of competitor regardless of drought. 
Table 3. Differences between ammonium $\left(\mathrm{NH}_{4}^{+}\right)$, nitrate $\left(\mathrm{NO}_{3}^{-}\right)$, glutamine-N $(\mathrm{Gln}-\mathrm{N})$ and arginine-N (Arg-N) net uptake capacity of the fine roots of $F$. sylvatica, $Q$. robur and $P$. sylvestris seedlings grown in competition under drought and control conditions. Only significant differences are presented. $\mathrm{n} . \mathrm{s}$.: no significant differences between net uptake capacity of different $\mathrm{N}$ forms.

\begin{tabular}{|c|c|c|c|c|}
\hline Competitor & Water availability & Fagus sylvatica & Quercus robur & Pinus sylvestris \\
\hline \multirow[t]{2}{*}{ Prunus serotina } & Control & Gln- $\mathrm{N}, \operatorname{Arg}-\mathrm{N}>\mathrm{NH}_{4}{ }^{+}$ & $\operatorname{Arg}-\mathrm{N}>\mathrm{NH}_{4}{ }^{+}, \mathrm{Gln}-\mathrm{N}$ & $\begin{array}{l}\mathrm{NO}_{3}^{-}, \mathrm{Gln}-\mathrm{N}^{-} \\
\text {Arg- } \mathrm{N}>\mathrm{NH}_{4}^{+} \\
\text {Arg- } \mathrm{N}>\mathrm{NO}_{3}^{-}\end{array}$ \\
\hline & Drought & $\mathrm{NH}_{4}{ }^{+}$, Gln-N, Arg- $\mathrm{N}>\mathrm{NO}_{3}{ }^{-}$Arg- $\mathrm{N}>\mathrm{NH}_{4}{ }^{+}$ & $\begin{array}{l}\text { Arg- } \mathrm{N}>\mathrm{NH}_{4}{ }^{+}, \mathrm{NO}_{3}^{-}, \\
\text {Gln- } \mathrm{N} \\
\text { Gln- } \mathrm{N}>\mathrm{NO}_{3}^{-}\end{array}$ & $\begin{array}{l}\text { Arg- } \mathrm{N}>\mathrm{NH}_{4}{ }^{+}, \mathrm{NO}_{3}{ }^{-}, \\
\text {Gln- } \mathrm{N} \\
\mathrm{Gln}-\mathrm{N}>\mathrm{NO}_{3}{ }^{-}\end{array}$ \\
\hline \multirow[t]{2}{*}{ Robinia pseudoacacia } & Control & Gln- $\mathrm{N}$, Arg- $\mathrm{N}>\mathrm{NH}_{4}{ }^{+}, \mathrm{NO}_{3}^{-}$ & $\begin{array}{l}\text { Arg-N }>\mathrm{NH}_{4}{ }^{+}, \mathrm{Gln}-\mathrm{N} \\
\text { Gln- } \mathrm{N}>\mathrm{NH}_{4}{ }^{+}\end{array}$ & n.s. \\
\hline & Drought & Gln- $\mathrm{N}$, Arg- $\mathrm{N}>\mathrm{NH}_{4}^{+}, \mathrm{NO}_{3}^{-}$ & $\begin{array}{l}\text { Arg- } \mathrm{N}>\mathrm{NH}_{4}{ }^{+}, \mathrm{NO}_{3}{ }^{-}, \\
\mathrm{Gln}-\mathrm{N} \\
\mathrm{Gln}-\mathrm{N}>\mathrm{NO}_{3}{ }^{-}\end{array}$ & $\operatorname{Arg}-\mathrm{N}>\mathrm{NO}_{3}^{-}$ \\
\hline
\end{tabular}

Table 4. Differences between ammonium $\left(\mathrm{NH}_{4}^{+}\right)$, nitrate $\left(\mathrm{NO}_{3}^{-}\right)$, glutamine- $\mathrm{N}(\mathrm{Gln}-\mathrm{N})$ and arginine- $\mathrm{N}($ Arg- $\mathrm{N})$ net uptake capacity of the fine roots of $P$. serotina and R. pseudoacacia seedlings grown in competition under drought and control conditions. Only significant differences are presented. n.s.: no significant differences between net uptake capacity of different $\mathrm{N}$ forms.

\begin{tabular}{|c|c|c|c|}
\hline Competitor & Water availability & Prunus serotina & Robinia pseudoacacia \\
\hline Fagus sylvatica & $\begin{array}{l}\text { Drought } \\
\text { Control }\end{array}$ & $\begin{array}{l}\text { Arg-N }>\mathrm{NH}_{4}{ }^{+}, \mathrm{NO}_{3}{ }^{-}, \mathrm{Gln}-\mathrm{N} \\
\text { Gln-N, Arg-N }>\mathrm{NH}_{4}{ }^{+}, \mathrm{NO}_{3}^{-}\end{array}$ & $\begin{array}{l}\text { n.s. } \\
\mathrm{NO}_{3}{ }^{-}, \text {Gln-N, Arg- } \mathrm{N}>\mathrm{NH}_{4}{ }^{+} \\
\text {Arg- } \mathrm{N}>\mathrm{NO}_{3}{ }^{-}\end{array}$ \\
\hline Quercus robur & $\begin{array}{l}\text { Drought } \\
\text { Control }\end{array}$ & $\begin{array}{l}\text { Arg- } \mathrm{N}>\mathrm{NH}_{4}^{+}, \mathrm{NO}_{3}^{-} \\
\mathrm{NO}_{3}^{-}, \text {Arg- } \mathrm{N}>\mathrm{NH}_{4}^{+} \\
\text {Arg- } \mathrm{N}>\text { Gln- } \mathrm{N}\end{array}$ & $\begin{array}{l}\text { Arg- } \mathrm{N}>\mathrm{NH}_{4}{ }^{+}, \mathrm{NO}_{3}^{-} \\
\text {n.s. }\end{array}$ \\
\hline Pinus sylvestris & $\begin{array}{l}\text { Drought } \\
\text { Control }\end{array}$ & $\begin{array}{l}\text { Arg- } \mathrm{N}>\mathrm{NH}_{4}{ }^{+}, \mathrm{NO}_{3}{ }^{-}, \mathrm{Gln}-\mathrm{N} \\
\text { Gln-N, Arg- } \mathrm{N}>\mathrm{NH}_{4}{ }^{+}\end{array}$ & $\begin{array}{l}\text { n.s. } \\
\text { n.s. }\end{array}$ \\
\hline
\end{tabular}

\section{Discussion}

Drought reduces $\mathrm{N}$ acquisition among species, but allocation of $N$ to $N$ pools varies with species and competitor

In accordance with our hypothesis, inorganic and organic $\mathrm{N}$ acquisition of both native and invasive tree seedlings overall decreased in response to drought, confirming that tree $\mathrm{N}$ acquisition and soil water availability are strongly linked (e.g., Fotelli et al. 2002, 2004, Rennenberg et al. 2006, Gessler et al. 2017). The influence on organic $\mathrm{N}$ acquisition for tree species in competition is a novel insight provided by our work, while also confirming previous studies in which drought reduced the inorganic $\mathrm{N}$ acquisition of $\mathrm{F}$. sylvatica seedlings growing both in intra- and inter-specific competition (Fotelli et al. 2002). In plant communities, when soil water availability is reduced microbial activity is decreased, negatively impacting soil $\mathrm{N}$ mineralization processes, thus resulting in reduced soil $\mathrm{N}$ availability (Schimel et al. 2007, Hueso et al. 2012). Furthermore, soil $\mathrm{N}$ diffusion and mass flow are reduced (Rennenberg et al. 2009) and the composition of mycorrhizal communities that symbiotically provide plants with $\mathrm{N}$ is changed (e.g., Gessler et al. 2005, Leberecht et al. 2016).

Our studied tree species appear to show four different responses to drought regarding the allocation of $\mathrm{N}$ to $\mathrm{N}$ pools in the leaves and fine roots depending on the species and competitor. (i) Total soluble protein levels were reduced (in the leaves of Fagus and Quercus regardless of competitor, and in the fine roots of Prunus and Robinia competing with Pinus) as a consequence of reduced $\mathrm{N}$ acquisition and thus, $\mathrm{N}$ assimilation (Gessler et al. 2017). Storage proteins from vegetative tissue are degraded and remobilized leading to lower $\mathrm{N}$ in storage (e.g., Millard 1988, Staswick 1994, Millard and Grelet 2010). With potential leaf shedding as a consequence of drought and, consequently, $\mathrm{N}$ stored in the leaves being lost by the plant, the roots become an important tissue for $\mathrm{N}$ storage (Millard and Grelet 2010). In our study, the leaves were not (yet) shed at the time of the harvest, suggesting that $\mathrm{N}$ was likely still remobilized. (ii) In the fine roots of Robinia in competition with Fagus, the levels of total soluble proteins increased in response to drought likely due to the synthesis of protective proteins (Brunner et al. 2015), proteins with a role in dehydration tolerance (Close 1996, Kozlowski and Pallardy 2002) and/or proteins required for the development of root nodules for $\mathrm{N}_{2}$-fixing species (Verma et al. 1992) such as Robinia. (iii) Soluble amino acid levels decreased in the fine roots of Prunus when grown in competition with Quercus or Pinus in response to drought. This is likely due to amino acid degradation, their translocation to other plant tissues, their usage for protein synthesis and/or 
the usage of their carbon skeletons to produce alternative non-N-containing osmotic compounds, which not only decrease osmotic potential but also can function as cell membrane and metabolic protectants (Chaves et al. 2003). (iv) In contrast, total soluble amino acid levels increased in the leaves of Robinia and the fine roots of Pinus regardless of competitor, as well as in the leaves and fine roots of Quercus in competition with Prunus via protein degradation to serve as osmoprotectants, thus improving the overall plant water status ( $\mathrm{Hu}$ et al. 2013a, 2013b). Overall, our results indicate that the study species show different responses to drought conditions in this short-term experiment with regards to $\mathrm{N}$ allocation to $\mathrm{N}$ pools in leaves and fine roots in combination with changes in biomass allocation.

Some species showed changes in biomass allocation in response to drought while others did not. A higher root:shoot ratio resulting in a larger soil volume to be exploited and a parallel decrease in aboveground biomass as well as SLA reduces water loss via the leaves further improving a plant's water status (Fotelli et al. 2005, Mantovani et al. 2014, Duan et al. 2018). This strategy was found in our study for Robinia. On the other hand, drought sensitivity of a species might be reflected by reduced root growth, eventually leading to a decrease in root:shoot ratio (Ostonen et al. 2007, Brunner et al. 2015), root hydraulic failure (Mao et al. 2018) and higher root mortality (Zhou et al. 2018). In our study, drought conditions were severe enough to cause a decrease in root:shoot ratio for Fagus indicating the drought-sensitivity of this species, but not the other native or the invasive species.

In general, all study species were negatively affected by drought with no clear distinction between native and invasive species. Native Fagus and - to a lesser extent-invasive Robinia were most sensitive, showing several changes in above- and below-ground traits. For Fagus, the strong response to drought generally prevailed over the effects of the competitor, while for Robinia it was mediated by the competitor. The ability to fix $\mathrm{N}_{2}$ allows Robinia to obtain external $\mathrm{N}$ and thus be less affected by the negative effect of drought on $\mathrm{N}$ acquisition from the soil (Mantovani et al. 2014, 2015, Wurzburger and Miniat 2014). For Quercus and invasive Prunus, responses to drought also varied according to competitor. In contrast, we found no interaction between drought and competitor for Pinus, which indicates that the two invasive species did not influence its response to drought. Furthermore, coniferous Pinus was generally less responsive to drought than the native and invasive deciduous species most likely due to its isohydric behavior, i.e., the closing of stomata early during a drought event, thereby minimizing water losses via the needles (Irvine et al. 1998). These results imply that under future scenarios of global change, Pinus can withstand simultaneous short-term drought stress and an invasion by exotic woody species better than Fagus and Quercus.
Species-specific responses of native and invasive species in response to competitor and soil water availability

Our hypothesis that $\mathrm{N}$ acquisition from the soil and its allocation to plant internal $\mathrm{N}$ pools vary for a given species depending on its functional traits and the competing species could partly be confirmed. None of the native species and only one of the two invasives responded to different competitors with changes in $\mathrm{N}$ acquisition, thus contrasting previous studies (Simon et al. 2010, 2014, Bueno et al. 2019). This suggests that soil water availability was a stronger driver of $\mathrm{N}$ uptake than competition. The allocation of $\mathrm{N}$ to different $\mathrm{N}$ pools of our studied species depended on the competitor and varied with soil water availability, thus confirming our hypothesis that responses to different competitors are speciesspecific according to the physiological characteristics of the study species.

Both invasive species in our study show functional traits commonly linked to fast growth (Grotkopp and Rejmánek 2007), such as higher biomass (Prunus) or higher SLA, and in turn, RGR (Robinia), higher $\mathrm{N}$ allocation to $\mathrm{N}$ pools in leaves and fine roots thus enhancing resource acquisition above- and belowground, and overall increasing their competitive advantage under high resource availability (e.g., Li et al. 2015). A negative influence of Robinia on the growth of competing tree seedlings has been reported before via the depletion of soil resources due to Robinia's fast growth and occupation of rooting space (Kawaletz et al. 2013, 2014). In our study, Robinia was the only species with increased rootshoot ratio under drought, suggesting a strong potential for below ground competition and resource gain for metabolic processes, which apparently had a stronger effect on drought-sensitive Fagus than the drought-tolerant natives. Nitrogen acquisition of all three native species did not differ with competitor, and the higher allocation of $\mathrm{N}$ to $\mathrm{N}$ pools combined with slower growth of Quercus and Pinus when competing with Prunus than Robinia suggests an increased storage of $\mathrm{N}$ metabolites rather than a use for biomass production (Reich et al. 1997, Millet et al. 2005, Millard and Grelet 2010). Moreover, the negative effects on growth and biomass indices when competing with Prunus rather than Robinia further indicate negative consequences of competition with Prunus for overall plant development.

Similar to the native species, the competitor had no effect on $\mathrm{N}$ acquisition of Prunus, indicating that the observed changes in biomass and growth indices as well as $\mathrm{N}$ metabolites content occurred in relation to internal $\mathrm{N}$ dynamics in the seedlings. This is likely due to remobilization and de novo synthesis of $\mathrm{N}$ metabolites (Simon et al. 2010, Li et al. 2015), and/or the reliance on $\mathrm{N}$ stored in plant tissues as $\mathrm{N}$-based defense compounds (Gleadow and Woodrow 2002). The other responses of invasive Prunus to native species depended on soil water availability. For example, drought-sensitive Fagus was a stronger 
competitor for Prunus only with sufficient soil water availability, whereas this effect was absent with drought, reflecting the drought-sensitivity of Fagus. With drought, N pools of Prunus were higher in competition with Pinus compared with deciduous natives. This indicates a similar mechanism of metabolic adaptation to stress as in the slow growing deciduous Fagus and Quercus (Millard and Grelet 2010). This might be a differential response of Prunus to specific competitors with drought conditions, possibly related to the drought tolerance of such competitors. This would be in accordance with studies indicating that evergreen conifers are on average more drought-tolerant due to their more conservative resource use than broadleaved deciduous temperate woody species (Hallik et al. 2009), though further studies considering a greater number of species are needed to provide additional insights into this.

Robinia responded to competition with native deciduous Fagus and Quercus more strongly than with coniferous Pinus, although the affected specific growth and physiological parameters depended on soil water availability. In contrast to all other study species, nitrate acquisition of Robinia was reduced in its competition with Fagus compared with competition with Pinus, suggesting the release of active compounds that potentially impair $\mathrm{N}$ acquisition as suggested for $A$. pseudoplatanus in a previous study (Simon et al. 2010). This would negatively affect nutrition and development of Robinia seedlings compared with competition with other natives because although Robinia can fix $\mathrm{N}_{2}, \mathrm{~N}$ acquisition from the soil is preferred over $\mathrm{N}_{2}$ fixation when soil $N$ is not limiting (Pfautsch et al. 2009). These differences in the responses to competitors became more apparent when Robinia was additionally affected by drought and may be explained by de novo synthesis of proteins as an adaptation to competition (Simon et al. 2010, 2014). Additionally, Robinia seedlings grew slower in competition with Fagus or Quercus compared with Pinus regardless of soil water availability, further highlighting their negative competitive effects on Robinia.

Overall, native and invasive species responded to different competitors in accordance with their physiological and life history traits such as drought tolerance and leaf habit. For example, drought-sensitive Fagus responded negatively to different competitors and affected invasive species only with sufficient water supply, indicating that drought effects override those of the two invasive competitors. Moreover, invasive Prunus was generally a stronger competitor for the native species. With competition, tissue nutrient content plays an important role in plant performance. For example, seedlings of black spruce (Picea mariana) with high levels of $\mathrm{N}$ (and other nutrients) had higher biomass than seedlings with low tissue $\mathrm{N}$ content after growing in competition with natural vegetation (Malik and Timmer 1998), indicating the importance of plant internal $\mathrm{N}$ reserves in competitive interactions.
Organic $N$ was generally preferred by all species regardless of drought

We hypothesized that native and invasive species differ in their preference for organic and inorganic $\mathrm{N}$ sources. However, organic $\mathrm{N}$ forms, especially arginine, were generally preferred over inorganic $\mathrm{N}$ by all study species, confirming results from studies in the field and under controlled settings (Simon et al. 2017) using the same technique and artificial soil solution as here (e.g., for F. sylvatica: Dannenmann et al. 2009, Simon et al. 2010, 2011, 2014, for R. pseudoacacia: Hu et al. 2017), as well as the results found at low soil $\mathrm{N}$ availability in our previous study using the same species (Bueno et al. 2019). The preferred acquisition of specific $\mathrm{N}$ sources is generally driven by their higher abundance in the soil (e.g., Kuster et al. 2013b, Song et al. 2015, Simon et al. 2017). For native Fagus and Pinus, as well as invasive Robinia, preferences shifted depending on the competitor (see Tables 3 and 4), indicating plasticity in resource use induced by the interaction with other species that might influence the plant's competitive ability (Ashton et al. 2010). Such shifts were not found for native Quercus and invasive Prunus, indicating that competition does not affect their $\mathrm{N}$-form preference. Furthermore, to our knowledge, no previous studies have directly measured the effect of drought on the preference for different $\mathrm{N}$ forms. We found no changes in the $\mathrm{N}$-form preference with drought, suggesting that changes in $\mathrm{N}$ preference for the study species do not play a role for adapting to drought, at least under these experimental conditions.

\section{Conclusions}

In our study, drought generally reduced inorganic and alsoshown for the first time-organic $\mathrm{N}$ acquisition among both native and invasive study species, because reduced water availability leads to less $\mathrm{N}$ available in the soil for plants. Overall, $\mathrm{N}$ acquisition was driven by water supply rather than competition. The allocation of $\mathrm{N}$ to internal $\mathrm{N}$ pools in the leaves and fine roots, however, varied with study species and competitor in relation to their physiological characteristics showing their respective species-specific coping mechanisms (e.g., the remobilization of $\mathrm{N}$ from storage and/or synthesis of osmoprotectants). For example, within the native tree species, for droughtsensitive Fagus, reduced water availability overrode the influence of competition, whereas the responses of drought-tolerant Pinus were entirely independent of water supply. Deciduous and coniferous species might respond differently to competition with other plants because of their differences in, for example, tissue concentrations of nutrients (Calder et al. 2011, Wang et al. 2016). Organic $N$ was generally favoured by both native and invasive species regardless of drought, suggesting that competition for $\mathrm{N}$ was not avoided. Moreover, our results suggest that Prunus as an invasive species is a stronger competitor than 
Robinia for most native tree species (which is in accordance with a previous study, Bueno et al. 2019), possibly due to its higher biomass. In contrast, for Robinia, the deciduous natives Fagus and Quercus had more negative effects than the conifer Pinus. In conclusion, our results suggest that species-specific mechanisms to cope with drought related to their physiological characteristics might play a role for the competitive ability of the studied species. However, further studies investigating a larger number of species are necessary to confirm this. Because water availability strongly affects plant and soil $\mathrm{N}$ dynamics (e.g., Gessler et al. 2017, Simon et al. 2017), longer term competition ( $>1$ year) might further pronounce the effects of competition seen in our study.

\section{Data and materials accessibility}

Data will be available from the Dryad Digital Repository under Data from: Responses of native and invasive woody seedlings to combined competition and drought are species-specific.

\section{Acknowledgments}

We are grateful to Leonhard Schink and Leia Mijatovic for their help with the ${ }^{15} \mathrm{~N}$ uptake experiments, harvest and sample processing. Furthermore, we would like to thank Silvia Kuhn and Roswitha Miller for their help with sample analyses. We thank Franz Buegger for the EA-IRMS analyses. We would also like to thank Iljas Müller, Gudrun Winter, Dietmar Funck, Marie-Luise Fritschka, Anna Märkle, Dominic Stickel, Lea Held, Inna Koleber, Julia Maier and Jasmin Thierschmidt for their assistance with parts of the harvest and sample processing. We thank the gardeners at the Botanical Garden of the University of Konstanz for their help with the planting of the mesocosms.

\section{Funding}

Funding was provided by the Young Scholar Fund project no. 83979115 of the University of Konstanz. J.S. was financially supported by a Heisenberg Fellowship of the German Research Foundation (DFG; grant no. SI 1556/2-1).

\section{Conflict of Interest}

The authors declare no conflict of interest.

\section{Authors' contributions}

A.B. and J.S. conceived and designed the study. A.B. conducted the ${ }^{15} \mathrm{~N}$ uptake experiments and $\mathrm{N}$ metabolite analyses, and evaluated all data. K.P. contributed the IRMS analyses. A.B. and J.S. led the writing of the manuscript. All authors contributed critically to the drafts and gave final approval for publication.

\section{References}

Anderson M, Gorley R, Clarke K (2008) PERMANOVA+ for PRIMER: guide to software and statistical methods. PRIMER-E, Plymouth.

Ashton IW, Miller AE, Bowman WD, Suding KN (2010) Niche complementarity due to plasticity in resource use: plant partitioning of chemical N forms. Ecology 91:3252-3260.

Bista DR, Heckathorn SA, Jayawardena DM, Mishra S, Boldt JK (2018) Effects of drought on nutrient uptake and the levels of nutrient-uptake proteins in roots of drought-sensitive and tolerant grasses. Plants (Basel) 7:28.

Boudsocq S, Niboyet A, Lata JC, Raynaud X, Loeuille N, Mathieu J, Blouin M, Abbadie L, Barot S (2012) Plant preference for ammonium versus nitrate: a neglected determinant of ecosystem functioning? Am Nat 180:60-69.

Broadbent A, Stevens CJ, Peltzer DA, Ostle NJ, Orwin KH (2018) Belowground competition drives invasive plant impact on native species regardless of nitrogen availability. Oecologia 186:577-587.

Brunner I, Herzog C, Dawes MA, Arend M, Sperisen C (2015) How tree roots respond to drought. Front Plant Sci 6:547.

Bueno A, Pritsch K, Simon J (2019) Species-specific outcome in the competition for nitrogen between invasive and native tree seedlings. Front Plant Sci 10:337.

Calder W, Horn K, St. Clair S (2011) Conifer expansion reduces the competitive ability and herbivore defense of aspen by modifying light environment and soil chemistry. Tree Physiol 31:582-591.

Campagnaro T, Brundub G, Sitzia T (2018) Five major invasive alien tree species in European Union forest habitat types of the alpine and continental biogeographical regions. J Nat Conserv 43:227-238.

Casper BB, Jackson RB (1997) Plant competition underground. Annu Rev Ecol Evol Syst 28:545-570.

Castro-Diez P, Pauchard A, Traveset A, Vilà M (2006) Linking the impacts of plant invasion on community functional structure and ecosystem properties. J Veg Sci 27:1233-1242.

Chaves MM, Maroco JP, Pereira JS (2003) Understanding plant responses to drought - from genes to the whole plant. Funct Plant Biol 30:239-264.

Close TJ (1996) Dehydrins: emergence of a biochemical role of a family of plant dehydration proteins. Physiol Plant 97:795-803.

Corbin JD, D'Antonio CM (2012) Gone but not forgotten? Invasive plants' legacies on community and ecosystem properties. Invas Plant Sci Manag 5:117-124.

Csiszár A (2009) Allelopathic effects of invasive woody plant species in Hungary. Acta Silv Lignaria Hung 5:9-17.

Dannenmann M, Simon J, Gasche R et al. (2009) Tree girdling provides insight on the role of labile carbon in nitrogen partitioning between soil microorganisms and adult European beech. Soil Biol Biochem 41:1622-1631.

Dawson W (2015) Release from belowground enemies and shifts in root traits as interrelated drivers of alien plant invasion success: a hypothesis. Ecol Evol 5:4505-4516.

Duan H, Huang G, Zhou S, Tissue D (2018) Dry mass production, allocation patterns and water use efficiency of two conifers with 
different water use strategies under elevated $\left[\mathrm{CO}_{2}\right]$, warming and drought conditions. Eur J For Res 137:605-618.

Eaton E, Caudullo G, Oliveira S, de Rigo D (2016) Quercus robur and Quercus petraea in Europe: distribution, habitat, usage and threats. In: San-Miguel-Ayanz J, de Rigo D, Caudullo G, Houston Durrant T, Mauri A (eds) European atlas of forest tree species. Publ. Off. EU, Luxembourg, p e01c6df+

Ehrenfeld JG (2003) Effects of exotic plant invasions on soil nutrient cycling processes. Ecosystems 6:503-523.

Ehrenfeld JG, Kourtev P, Huang W (2001) Changes in soil functions following invasions of exotic understory plants in deciduous forests. Ecol Appl 11:1287-1300.

Ellenberg $H$, Leuschner C (2010) Vegetation Mitteleuropas mit den Alpen, Vol. 6. Ulmer, Stuttgart, Germany.

Eller CB, Oliveira RS (2017) Effects of nitrogen availability on the competitive interactions between an invasive and a native grass from Brazilian cerrado. Plant Soil 410:63-72.

Fotelli MN, Gessler A, Peuke AD, Rennenberg H (2001) Drought affects the competitive interactions between Fagus sylvatica seedlings and an early successional species, Rubus fruticosus: responses of growth, water status and $\delta^{13} \mathrm{C}$ composition. New Phytol 151: 427-435.

Fotelli MN, Rennenberg H, Gessler A (2002) Effects of drought on the competitive interference of an early successional species (Rubus fruticosus) on Fagus sylvatica L. seedlings: ${ }^{15} \mathrm{~N}$ uptake and partitioning, responses of amino acids and other $\mathrm{N}$ compounds. Plant Biol $4: 311-320$.

Fotelli MN, Rienks M, Rennenberg H, Gessler A (2004) Climate and forest management affect ${ }^{15} \mathrm{~N}$-uptake, $\mathrm{N}$ balance and biomass of European beech seedlings. Trees 18:157-166.

Fotelli MN, Rudolph P, Rennenberg H, Gessler A (2005) Irradiance and temperature affect the competitive interference of blackberry on the physiology of European beech seedlings. New Phytol 165: 453-462.

Fraterrigo JM, Strickland MS, Keiser AD, Bradford MA (2011) Nitrogen uptake and preference in a forest understory following invasion by an exotic grass. Oecologia 167:781-791.

Gessler A, Schneider S, von Sengbusch D, Weber P, Hanemann U, Huber C, Rothe A, Kreutzer K, Rennenberg H (1998) Field and laboratory experiments on net uptake of nitrate and ammonium by the roots of spruce (Picea abies) and beech (Fagus sylvatica) trees. New Phytol 138:275-285.

Gessler A, Kreuzwieser J, Dopatka T, Rennenberg H (2002) Diurnal courses of ammonium net uptake by the roots of adult beech (Fagus sylvatica) and spruce (Picea abies) trees. Plant Soil 240:23-32.

Gessler A, Keitel C, Nahm M, Rennenberg H (2004) Water shortage affects the water and nitrogen balance in central European beech forests. Plant Biol 6:289-298.

Gessler A, Jung K, Gasche R et al. (2005) Climate and forest management influence nitrogen balance of European beech forests: microbial $\mathrm{N}$ transformations and inorganic $\mathrm{N}$ net uptake capacity of mycorrhizal roots. Eur J For Res 124:95-111.

Gessler A, Schaub M, McDowell NG (2017) The role of nutrients in drought-induced tree mortality and recovery. New Phytol 214:513-520.

Gleadow RM, Woodrow IE (2002) Constraints on effectiveness of cyanogenic glycosides in herbivore defense. J Chem Ecol 28:1297-1309.

Grotkopp E, Rejmánek M (2007) High seedling relative growth rate and specific leaf area are traits of invasive species: phylogenetically independent contrasts of woody angiosperms. Am J Bot 94: 526-532.

Grubb PJ, Lee WG, Kollmann J, Wilson JB (1996) Interaction of irradiance and soil nutrient supply on growth of seedlings of ten European tall-shrub species and Fagus sylvatica. J Ecol 84:827-840.
Hallik L, Niinemets Ü, Wright IJ (2009) Are species shade and drought tolerance reflected in leaf-level structural and functional differentiation in northern hemisphere temperate woody flora? New Phytol 184:257-274.

Holmes TP, Aukema JE, Von Holle B, Liebhold A, Sills E (2009) Economic impacts of invasive species in forests-past, present, and future. Ann N Y Acad Sci 1162:18-38.

Houston T, de Rigo D, Caudullo G (2016) Fagus sylvatica and other beeches in Europe: distribution, habitat, usage and threats. In: SanMiguel-Ayanz J, de, Rigo D, Caudullo G, Houston T, Mauri A (eds) European atlas of forest tree species. Publ. Off. EU, Luxembourg, p $\mathrm{e} 012 \mathrm{~b} 90+$.

Hu B, Simon J, Kuster TM, Arend M, Siegwolf R, Rennenberg H (2013a) Nitrogen partitioning in oak leaves depends on species, provenance, climate conditions, and soil type. Plant Biol 15:198-209.

Hu B, Simon J, Rennenberg H (2013b) Drought and air warming affect the species-specific levels of stress-related foliar metabolites of three oak species on acidic and calcareous soil. Tree Physiol 33:489-504.

Hu B, Zhou M, Dannenmann M et al. (2017) Comparison of nitrogen nutrition and soil carbon status of afforested stands established in degraded soil of the loess plateau, China. For Ecol Manage 389:46-58.

Huangfu C, Li H, Chen X, Liu H, Wang H, Yang D (2016) Response of an invasive plant, Flaveria bidentis, to nitrogen addition: a test of form-preference uptake. Biol Invasions 18:3365-3380.

Hueso S, García C, Hernández T (2012) Severe drought conditions modify the microbial community structure, size and activity in amended and unamended soils. Soil Biol Biochem 50:167e173.

Irvine J, Perks MP, Magnani F, Grace J (1998) The response of Pinus sylvestris to drought: stomatal control of transpiration and hydraulic conductance. Tree Physiol 18:393-402.

Kawaletz H, Mölder I, Zerbe S, Annighöfer P, Terwei A, Ammer C (2013) Exotic tree seedlings are much more competitive than natives but show underyielding when growing together. Plant Ecol 6:305-315.

Kawaletz H, Mölder I, Annighöfer P, Terwei A, Zerbe S, Ammer C (2014) Back to the roots: how do seedlings of native tree species react to the competition by exotic species? Ann For Sci 71:337-347.

Kozlowski TT, Pallardy SG (2002) Acclimation and adaptive responses of woody plants to environmental stresses. Bot Rev 68:270-334.

Kreuzwieser J, Furniss S, Rennenberg H (2002) Impact of waterlogging on the $\mathrm{N}$-metabolism of flood tolerant and non-tolerant tree secies. Plant Cell Environ 25:1039-1049.

Kuster TM, Arend M, Günthardt-Goerg MS, Schulin R (2013a) Root growth of different oak provenances in two soils under drought stress and air warming conditions. Plant Soil 369:61-71.

Kuster TM, Schleppi P, Hu B, Schulin R, Günthardt-Goerg MS (2013b) Nitrogen dynamics in oak model ecosystems subjected to air warming and drought on two different soils. Plant Biol 15:220-229.

Lamarque LJ, Delzon S, Lortie CJ (2011) Tree invasions: a comparative test of the dominant hypotheses and functional traits. Biol Invasions 13:1969-1989.

Leberecht M, Tu J, Polle A (2016) Acid and calcareous soils affect nitrogen nutrition and organic nitrogen uptake by beech seedlings (Fagus sylvatica L.) under drought, and their ectomycorrhizal community structure. Plant Soil 409:143-157.

Leishman MR, Haslehurst T, Ares A, Baruch Z (2007) Leaf trait relationships of native and invasive plants: community- and global-scale comparisons. New Phytol 176:635-643.

Li X, Rennenberg H, Simon J (2015) Competition for nitrogen between Fagus sylvatica and Acer pseudoplatanus seedlings depends on soil nitrogen availability. Front Plant Sci 6:302.

Littschwager J, Lauerer M, Blagodatskaya E, Kuzyakov Y (2010) Nitrogen uptake and utilisation as a competition factor between invasive Duchesnea indica and native Fragaria vesca. Plant Soil 331:105-114. 
Liu XP, Grams T, Matyssek R, Rennenberg H (2005) Effects of elevated $\mathrm{pCO}_{2}$ and/or $\mathrm{pO}_{3}$ on $\mathrm{C}$-, $\mathrm{N}$-, and S-metabolites in the leaves of juvenile beech and spruce differ between trees grown in monoculture and mixed culture. Plant Physiol Biochem 43:147-154.

Liu Y, van Kleunen M (2017) Responses of common and rare aliens and natives to nutrient availability and fluctuations. I Ecol 105:1111-1122.

Malik V, Timmer VR (1998) Biomass partitioning and nitrogen retranslocation in black spruce seedlings on competitive mixedwood sites: a bioassay study. Can J For Res 28:206-215.

Mantovani D, Veste M, Freese D (2014) Effects of drought frequency on growth performance and transpiration of young black locust (Robinia pseudoacacia L.). Int J For Res 2014:821891.

Mantovani D, Veste M, Boldt-Burisch K, Fritsch S, Koning LA, Freese D (2015) Carbon allocation, nodulation, and biological nitrogen fixation of black locust (Robinia pseudoacacia L.) under soil water limitation. Ann For Res 58:259-274.

Mao W, Felton AJ, Ma Y, Zhang T, Sun Z, Zhao X, Smith MD (2018) Relationships between aboveground and belowground trait responses of a dominant plant species to alterations in watertable depth. Land Degrad Dev 29:4015-4024.

Mason RAB, Cooke J, Moles AT, Leishman MR (2008) Reproductive output of invasive versus native plants. Glob Ecol Biogeogr 17:633-640.

McDowell SCL (2002) Photosynthetic characteristics of invasive and noninvasive species of Rubus (Rosaceae). Am J Bot 89:1431-1438.

McKane R, Johnson L, Shaver G et al. (2002) Resource-based niches provide a basis for plant species diversity and dominance in arctic tundra. Nature 412:68-71.

Millard P (1988) The accumulation and storage of nitrogen by herbaceous plants. Plant Cell Environ 11:1-8.

Millard P, Grelet GA (2010) Nitrogen storage and remobilization by trees: ecophysiological relevance in a changing world. Tree Physiol 30:1083-1095.

Millet J, Millard P, Hester AJ, McDonald AJS (2005) Do competition and herbivory alter the internal nitrogen dynamics of birch saplings? New Phytol 168:413-422.

Näsholm T, Kielland K, Ganeteg U (2009) Uptake of organic nitrogen by plants. New Phytol 182:31-48.

Nilsen P, Børja I, Knutsen H, Brean R (1998) Nitrogen and drought effects on ectomycorrhizae of Norway spruce [Picea abies L. (Karst.)]. Plant Soil 198:179-184.

Ostonen I, Püttsepp Ü, Biel C et al. (2007) Specific root length as an indicator of environmental change. Plant Biosyst 141:426-442.

Pattison RR, Goldstein G, Ares A (1998) Growth, biomass allocation and photosynthesis of invasive and native Hawaiian rainforest species. Oecologia 117:449-459.

Pfautsch S, Rennenberg H, Bell TL, Adams MA (2009) Nitrogen uptake by Eucalyptus regnans and Acacia spp.-preferences, resource overlap and energetic costs. Tree Physiol 29:389-399.

Reich PB (2014) The world-wide 'fast-slow' plant economics spectrum: a traits manifesto. J Ecol 102:275-301.

Reich PB, Walters MB, Ellsworth DS (1997) From tropics to tundra: global convergence in plant functioning. Proc Natl Acad Sci USA 94:13730-13734.

Rennenberg $\mathrm{H}$, Loreto F, Polle A, Brilli F, Fares S, Beniwal RS, Gessler A (2006) Physiological responses of forest trees to heat and drought. Plant Biol 8:556-571.

Rennenberg $\mathrm{H}$, Dannenmann M, Gessler A, Kreuzwieser J, Simon J, Papen $\mathrm{H}$ (2009) Nitrogen balance in forest soils: nutritional limitation of plants under climate change stresses. Plant Biol 11:4-23.

Ricciardi A (2007) Are modern biological invasions an unprecedented form of global change? Conserv Biol 21:329-336.
Robakowski P, Bielinis E, Stachowiak J, Mejza I, Bułaj B (2016) Seasonal changes affect root prunasin concentration in Prunus serotina and override species interactions between $P$. serotina and Quercus petraea. J Chem Ecol 42:202-214.

Schimel J, Balser TC, Wallenstein M (2007) Microbial stress-response physiology and its implications for ecosystem function. Ecology 88:1386-1394.

Simon J, Waldhecker P, Brüggemann N, Rennenberg H (2010) Competition for nitrogen sources between European beech (Fagus sylvatica) and sycamore maple (Acer pseudoplatanus) seedlings. Plant Biol 12:453-458.

Simon J, Dannenmann M, Gasche R et al. (2011) Competition for nitrogen between adult European beech and its offspring is reduced by avoidance strategy. For Ecol Manage 262:105-114.

Simon J, Li X, Rennenberg H (2014) Competition for nitrogen between European beech and sycamore maple shifts in favour of beech with decreasing light availability. Tree Physiol 34:49-60.

Simon J, Dannenmann M, Pena R, Gessler A, Rennenberg H (2017) Nitrogen nutrition of beech forests in a changing climate: importance of plant-soil-microbe water, carbon, and nitrogen interactions. Plant Soil 418:89-114.

Sohn JA, Hartig F, Kohler M, Huss J, Bauhus J (2016) Heavy and frequent thinning promotes drought adaptation in Pinus sylvestris forests. Ecol Appl 26:2190-2205.

Song M, Zheng L, Suding KN, Yin T, Yu F (2015) Plasticity in nitrogen form uptake and preference in response to long-term nitrogen fertilization. Plant Soil 394:215-224.

Spinoni J, Vogt JV, Naumann G, Barbosa P, Dosio A (2017) Will drought events become more frequent and severe in Europe? Int I Climatol 38:1718-1736.

Staswick PE (1994) Storage proteins of vegetative plant tissues. Annu Rev Plant Physiol Plant Mol Biol 45:303-322.

Verma DPS, Hu CA, Zhang M (1992) Root nodule development: origin, function and regulation of nodulin genes. Physiol Plant 85: 253-265.

Vilà M, Espinar JL, Hejda M et al. (2011) Ecological impacts of invasive alien plants: a meta-analysis of their effects on species, communities and ecosystems. Ecol Lett 14:702-708.

Vítková M, Müllerová J, Sádlo J, Pergl J, Pyšek P (2017) Black lacust (Robinia pseudoacacia) beloved and despised: a story of an invasive tree in Central Europe. For Ecol Manage 384: 287-302.

Vitousek PM, Aber JD, Howarth RW, Likens GE, Matson PA, Schindler DW, Schlesinger WH, Tilman DG (1997) Human alteration of the global nitrogen cycle: sources and consequences. Ecol Appl 7:737-750.

Wang $\mathrm{H}$, Liu S, Wang J et al. (2016) Differential effects of conifer and broadleaf litter inputs on soil organic carbon chemical composition through altered soil microbial community composition. Sci Rep 6:27097.

Wardle DA, Peltzer DA (2017) Impacts of invasive biota in forest ecosystems in an aboveground-belowground context. Biol Invasions 19:3301-3316.

Winter H, Lohaus G, Heldt HW (1992) Phloem transport of aminoacids in relation to their cytosolic levels in barley leaves. Plant Physiol 99:996-1004

Wurzburger N, Miniat CF (2014) Drought enhances symbiotic dinitrogen fixation and competitive ability of a temperate forest tree. Oecologia 174:1117-1126.

Zhou G, Zhou X, Nie Y, Bai SH, Zhou L, Shao J, Cheng W, Wang J, Hu F, Fu $Y$ (2018) Drought-induced changes in root biomass largely result from altered root morphological traits: evidence from a synthesis of global field trials. Plant Cell Environ 41:2589-2599. 